\title{
Clinical and histological effects of the temporary occlusion of the rabbit nasolacrimal duct and point using cyanoacrylate adhesives
}

\author{
[Efeitos clínicos e histológicos da oclusão temporária do ponto e do duto nasolacrimais de \\ coelhos com adesivos de cianoacrilato] \\ K.C.F. Cardoso ${ }^{1}$, M.A. Ferreira ${ }^{1}$, M.P. Miguel $^{2}$, A.A. Bolzan ${ }^{3}$, C.T.D. Nishimori ${ }^{4}$, \\ L.G. Franco ${ }^{5}$, C.S. Honsho ${ }^{5}$ \\ ${ }^{1}$ Aluno de pós-graduação - Universidade de Franca-UNIFRAN - Franca, SP \\ ${ }^{2}$ Universidade Federal de Goiás-UFG - Jataí, GO \\ ${ }^{3}$ Faculdade de Medicina Veterinária e Zootecnia - Universidade de São Paulo-USP - São Paulo, SP \\ ${ }^{4}$ Universidade Federal de Goiás-UFG - Goiânia, GO \\ ${ }^{5}$ Universidade de Franca-UNIFRAN - Franca, SP
}

\begin{abstract}
The objective of this study was to evaluate the clinical and histological effects of occluding the nasolacrimal ducts and points of rabbits. For this study, 20 adult New Zealand rabbits, both males and females, weighing $3.2 \pm 0.4 \mathrm{~kg}$ were allocated into two groups for n-butyl-cyanoacrylate occlusion (GB, $\mathrm{n}=10)$ or 2-octyl-cyanoacrylate occlusion $(\mathrm{GO}, \mathrm{n}=10)$. The contralateral eyes served as the controls. The persistence of tears was evaluated daily using the Schirmer I test. Discomfort, eye discharge, epiphora, and conjunctival hyperemia were assessed prior to the procedure (T0) and during the 14 subsequent days (T1-T14). On days seven and 14, five animals from each group were euthanized, and their nasolacrimal ducts were collected, processed and analyzed by histology. In the GB group, the Schirmer test values differed from that at $\mathrm{T} 0$ at all of the subsequent time points, whereas there was no difference in the values observed from the GO group. Compared with the corresponding controls, the GO and GB groups differed significantly at almost all of the time points. When comparing the treatment groups, differences were found at T6, T7, T9, T10, T11, T12 and T14, with higher Schirmer values in the GB group. Epiphora was observed in the GB group from $\mathrm{T} 1$ to $\mathrm{T} 8$ and in the GO group from $\mathrm{T} 1$ to T6. Within seven days postocclusion, histology revealed a moderate foreign body reaction, with marked necrosis and sloughing of the canalicular epithelium, in the GO group, which was absent at day 14. In the GB group, a marked inflammatory reaction and a mild foreign body reaction were found at day seven, and the foreign body reaction was prevalent at day 14 . This study demonstrated that both adhesives were effective in obstructing the nasolacrimal ducts and points of rabbits and that their application and handling are easy and free of complications. However, both adhesives promoted inflammatory and foreign body reactions that evolved to repair and regeneration at day 14 of evaluation.
\end{abstract}

Keywords: dry eye, keratoconjunctivitis sicca, Schirmer test, tear

\section{RESUMO}

Avaliaram-se os efeitos clínicos e histológicos da oclusão do ponto e do duto nasolacrimais de coelhos. Para isso, utilizaram-se 20 coelhos adultos da raça Nova Zelândia, machos e fêmeas, com peso de $3,2 \pm 0,4 \mathrm{~kg}$, distribuídos em dois grupos: oclusão com n-butil cianoacrilato $(G B, n=10)$ e oclusão com 2 octil cianoacrilato $(G O, n=10)$. Os olhos contralaterais foram utilizados como controle. A permanência da lágrima foi avaliada diariamente pelo teste de Schirmer I. Foram avaliados o desconforto, secreção ocular, epífora e hiperemia conjuntival, previamente ao procedimento (TO) e durante 14 dias (T1-T14). Aos sete e aos 14 dias, cinco animais de cada grupo foram submetidos à eutanásia, e os dutos

Recebido em 9 de outubro de 2012

Aceito em 6 de agosto de 2013

*Autor para correspondência (corresponding author)

E-mail: crishonsho@unifran.br 
nasolacrimais, colhidos, processados e analisados à histologia. Em GB, os valores de Schirmer diferiram de TO em todos os momentos; em GO não houve diferença. Na comparação com o respectivo controle, $G B$ e GO diferiram significativamente em quase todos os momentos. Ao compararem-se os tratamentos, houve diferença em T6, T7, T9, T10, T11, T12 e T14, sendo os valores de Schirmer superiores em GB. Epífora esteve presente em GB de Tl a T8 e em GO de Tl a T6. À histologia, em GO, aos sete dias, notou-se moderada reação de corpo estranho com marcante necrose e descamação do epitélio canalicular; tais alterações estiveram ausentes aos 14 dias. Em GB, verificou-se, aos sete dias, acentuada reação inflamatória e discreta reação de corpo estranho; aos 14 dias, houve predomínio da reação de corpo estranho. Concluiu-se que ambos os adesivos foram eficazes na obstrução do ponto e do duto nasolacrimais de coelhos, sendo sua aplicação e manuseio fáceis e livres de intercorrências e ambos promoveram reação inflamatória e de corpo estranho que evoluíram para reparação e regeneração aos 14 dias de avaliação.

Palavras-chave: ceratoconjuntivite seca, lágrima, olho seco, teste de Schirmer

\section{INTRODUCTION}

Keratoconjunctivitis sicca (KCS), or dry eye, is an inflammatory condition of the ocular surface, which often affects dogs, and it is characterized by pathologic reduction of eye lubrication (Gum et al., 2007; Williams, 2008). In dogs, the removal of the superficial lacrimal gland of the third eyelid (Slatter, 2005; Giuliano and Moore, 2007); lacrimal gland adenitis, which is caused by infectious diseases such as distemper or chronic blepharoconjunctivitis (Giuliano and Moore, 2007); the effects of drugs or drug toxicity (Slatter, 2005; Giuliano and Moore, 2007); orbital inflammatory disease or trauma; loss of the parasympathetic innervation of the lacrimal gland or sensory impairment of the ocular surface; systemic metabolic (Giuliano and Moore, 2007) or immune-mediated diseases (Berger et al., 1995; Slatter, 2005; Giuliano and Moore, 2007); congenital alacrima (Herrera $e t$ al., 2007), as well as breed (Berger et al., 1995; Slatter, 2005; Giuliano and Moore, 2007) may be involved in the pathogenesis of KCS.

The goal of establishing a treatment for patients with KCS is to maintain the lubrication of the ocular surface. Thus, occlusion of the nasolacrimal duct or point using drugs that stimulate tear production may facilitate the treatment of patients with KCS by maintaining naturally produced tears or synthesized analogs on the ocular surface, (Patel and Grierson, 1994; Diamond et al., 1995; Murube and Murube, 1996). This is a simple, safe and effective procedure. The occlusion may be temporary or permanent. For temporary occlusion, gelatin, collagen or silicone implants are indicated, and for permanent occlusion, thermal cauterization
(Patel and Grierson, 1994; Murube and Murube, 1996; Ohba et al., 2011), radiofrequency, laser, or even ligation of lacrimal canaliculus (Diamond et al., 1995; Murube and Murube, 1996; Ohba et al., 2011) may be performed.

Patten (1976) and Diamond et al. (1995) placed n-butyl-cyanoacrylate in human lacrimal and nasolacrimal ducts, respectively, and reported good results concerning the occlusions without, however, assessing tissue injuries associated with the procedures. Thus, using surgical-grade nbutyl cyanoacrylate and 2-octyl-cyanoacrylate adhesives, the feasibility of temporarily occluding the nasolacrimal ducts and points of rabbits was studied by evaluating the ease of implementation, the clinical outcomes and the histological findings.

\section{MATERIALS AND METHODS}

The research was conducted in compliance with the criteria of the Association for Research in Vision and Ophthalmology (ARVO) adopted as the ethical principles for animal research and with the approval and under the supervision of the Ethics Committee on Animal Use (CEUA), approved at a meeting on April 14, 2011 (protocol 008/11).

The study used 20 male and female albino New Zealand rabbits that were clinically healthy, weighed $3.2 \pm 0.4 \mathrm{~kg}$ and were kept in individual cages with commercial food and water ad libitum.

Two experimental groups were established: the n-butyl-cyanoacrylate group $(\mathrm{GB}, \mathrm{n}=10)$, in which the nasolacrimal duct of the left eye was 
occluded using n-butyl-cyanoacrylate (Vetbond ${ }^{\circledR}$ - 3M do Brasil, Sumaré, SP, Brasil) and the 2-octyl-cyanoacrylate group $(\mathrm{GO}, \mathrm{n}=10)$, in which the nasolacrimal duct of the left eye was occluded using 2-octyl cyanoacrylate (Dermabond $^{\circledR}$ - Johnson \& Johnson Medical Ltd., Livingston, Scotland). The contralateral eyes were used as controls.

To avoid interference from the stress caused by assessing the parameters, the animals were handled daily by the evaluator for five days prior to the occlusion.

To conduct the occlusion, the animals were premedicated with $1 \mathrm{mg} / \mathrm{kg}$ of xylazine hydrochloride (Rompum ${ }^{\circledR}$ - Bayer Saúde Animal, São Paulo, SP, Brasil) and $1 \% 1 \mathrm{mg} / \mathrm{kg}$ of morphine sulfate $1 \%\left(\right.$ Dimorf $^{\circledR}$ - Cristália Produtos Químicos Farmacêuticos Ltda., São Paulo, SP, Brasil), combined in the same syringe and administered intramuscularly. The induction and maintenance of anesthesia were accomplished using 10 to $15 \mathrm{mg} / \mathrm{kg}$ of propofol (Propovan ${ }^{\circledR}$ - Cristália Produtos Químicos Farmacêuticos Ltda., São Paulo, SP, Brasil) slowly administered intravenously.

Antisepsis of the ocular surface was maintained using a solution of saline and polyvinylpyrrolidone (PVP) at a ratio of 100:1, which was dried with a swab. To perform the occlusion, a $24-\mathrm{G}$ venous catheter coupled to a 1 $\mathrm{ml}$ syringe containing 0.1 to $0.2 \mathrm{~mL}$ of $\mathrm{n}$-butylcyanoacrylate or 2-octyl-cyanoacrylate was used. Approximately one centimeter of the catheter was inserted into the lacrimal point and the duct was filled with the adhesive using gentle pressure on the plunger, while slowly removing the catheter. The remnants of the glue on the ocular surface were gently removed with a cotton swab soon after it polymerized. The animals were kept in Elizabethan collars.

The presence of tears on the corneal surface was evaluated using the Schirmer tear test prior to any manipulation (T0) and daily for 14 days after the occlusion (T1-T14). The clinical assessments were conducted over the same period by the same observer, with blepharospasm and ocular discharge classified as present (+) or absent (-) and epiphora and conjunctival hyperemia classified by scores (0 - absent, 1 - mild, 2 moderate and 3 - severe).
At days seven and 14 post-occlusion, five animals from each group were euthanized using an overdose of anesthesia. To facilitate and guide the dissection of the nasolacrimal duct, a 24-G intravenous catheter was introduced, and the dissection was performed, including a margin of approximately $0.5 \mathrm{~cm}$. The collected samples, including the catheterized duct, were placed on cardstock and attached to it with hypodermic needles and then kept in $4 \%$ buffered formalin until they were embedded in paraffin. Histological sections transverse to the duct were stained with hematoxylin-eosin.

A descriptive histological analysis was performed to assess the tissues' reaction to the glues in a semi-quantitative way (acute inflammatory reaction, eosinophilic infiltrate, foreign body reaction, and granulation). The following reaction intensity scores were applied: absent (0), mild (1), moderate (2), and severe (3).

The data were statistically analyzed using the Jandel SigmaStat software program (SigmaStat $3.5^{\circledR}$ - Systat Software Inc., San Jose, California, USA) for Windows. For the Schirmer test values, an analysis of variance (ANOVA) followed by the Student-Newman-Keuls test was used to evaluate the differences between time points within each group. For comparison between the groups, the $\mathrm{t}$ test was employed.

The Kruskal-Wallis test was used to compare the conjunctival hyperemia, scleral congestion, epiphora, blepharospasm and ocular discharge over time within each group, and the Mann-Whitney test was used for comparisons between the groups. Differences were considered significant at $\mathrm{P} \leq 0.05$.

\section{RESULTS}

The mean Schirmer tear test result for the 40 eyes analyzed at the baseline (T0) was $7.25 \pm 2.96 \mathrm{~mm} / \mathrm{min}$. The Schirmer test results of the GO group significantly differed from those of its control group: $\mathrm{T} 0(\mathrm{P}=0.0049), \mathrm{T} 1(\mathrm{P}=0.0057)$, T2 $(\mathrm{P}=0.0011)$, T3 $(\mathrm{P}<0.0001), \mathrm{T} 4 \quad(\mathrm{P}<0.0001)$, T5 $(\mathrm{P}<0.001)$, T6 $(\mathrm{P}=0.0002), \mathrm{T} 7(\mathrm{P}=0.0028), \mathrm{T} 9$ $(\mathrm{P}=0.0263), \mathrm{T} 11 \quad(\mathrm{P}=0.0263), \mathrm{T} 12 \quad(\mathrm{P}=0.0147)$, $\mathrm{T} 13(\mathrm{P}=0.0006)$ and $\mathrm{T} 14(\mathrm{P}=0.0028)$. 
Comparing the values for the GB group revealed that they were different from that at $\mathrm{T} 0$ $(\mathrm{P}<0.001)$ at all other time points (Fig. 1A).

In the GO group, the Schirmer values were high compared to that of its control group at $\mathrm{T} 1$ $(\mathrm{P}=0.0003), \mathrm{T} 2 \quad(\mathrm{P}=0.0046), \mathrm{T} 3 \quad(\mathrm{P}<0.0001), \mathrm{T} 4$ $(\mathrm{P}=0.0006), \mathrm{T} 5 \quad(\mathrm{P}<0.0001), \mathrm{T} 6 \quad(\mathrm{P}=0.0078), \mathrm{T} 7$ $(\mathrm{P}=0.0066), \mathrm{T} 9(\mathrm{P}=0.001), \mathrm{T} 12(\mathrm{P}=0.0055)$ and $\mathrm{T} 14(\mathrm{P}=0.0436)$ (Fig. 1B).
When comparing the treatment groups, we found that the Schirmer test values differed significantly at T6 $(\mathrm{P}=0.0326), \mathrm{T} 7(\mathrm{P}=0.0018)$, T9 $\quad(\mathrm{P}=0.0032), \quad \mathrm{T} 10 \quad(\mathrm{P}=0.0278), \quad \mathrm{T} 11$ $(\mathrm{P}=0.0111), \quad \mathrm{T} 12 \quad(\mathrm{P}=0.0009) \quad$ and $\mathrm{T} 14$ $(\mathrm{P}=0.0447)$, with higher values in the $\mathrm{GB}$ group (Fig. 1C).
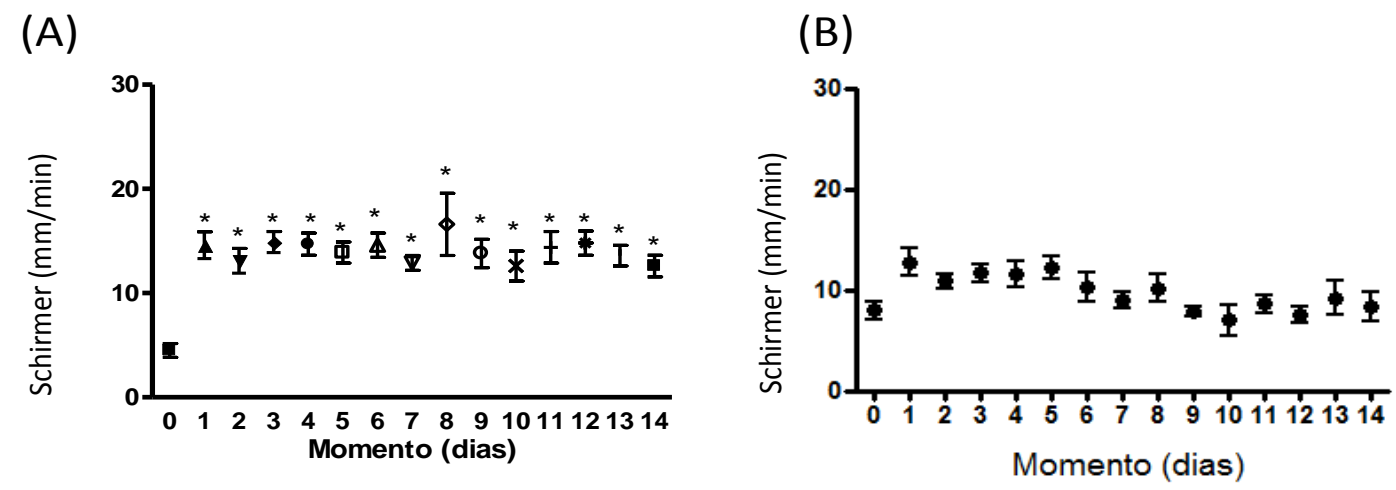

(C)

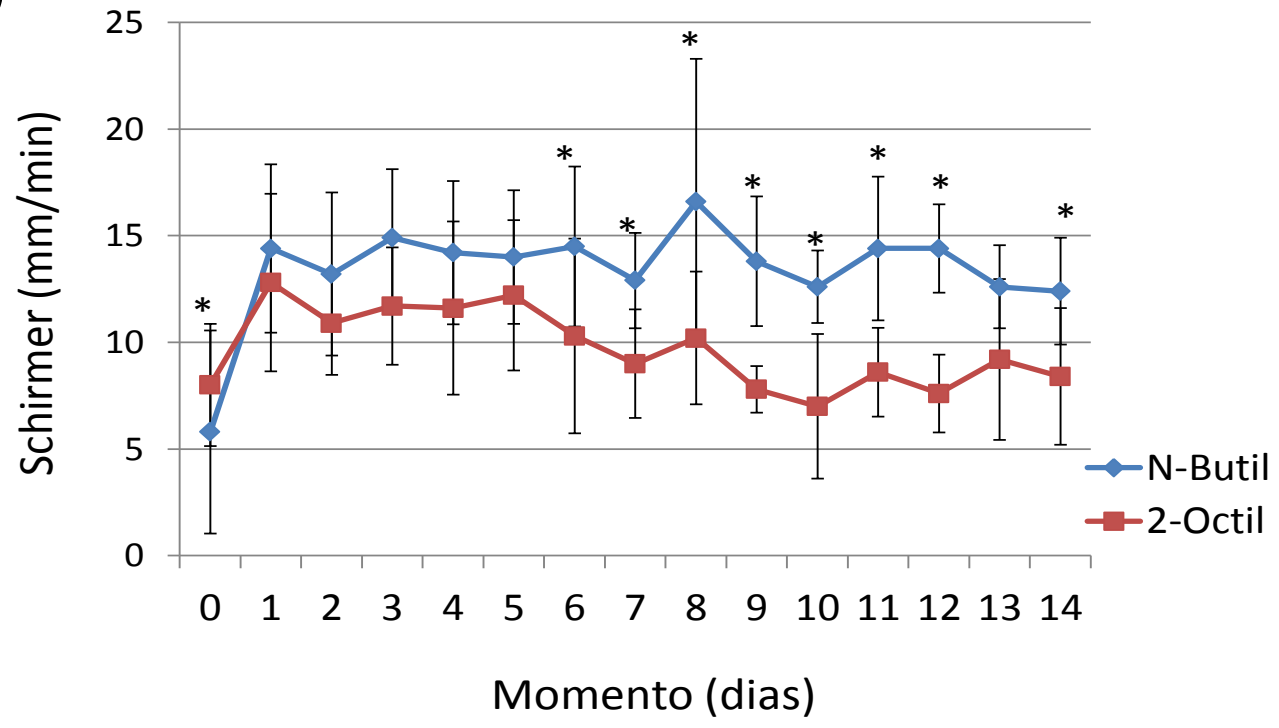

Figure 1. Graphs showing the values obtained using the Schirmer tear test in rabbits subjected to occlusion of the left nasolacrimal duct. In A, occlusion with n-butyl-cyanoacrylate $(\mathrm{GB}, \mathrm{n}=10)$; in $\mathrm{B}$, occlusion with 2-octyl-cyanoacrylate $(\mathrm{GO}, \mathrm{n}=10)$; in $\mathrm{C}$, GBxGO. *Significant difference at $\mathrm{P} \leq 0.05$. 
Epiphora was observed in the GB group at $\mathrm{T} 1$ $(\mathrm{P}<0.001), \quad \mathrm{T} 2 \quad(\mathrm{P}<0.001), \mathrm{T} 3 \quad(\mathrm{P}<0.001), \mathrm{T} 4$ $(\mathrm{P}<0.001), \quad$ T5 $\quad(\mathrm{P}<0.05), \quad$ T6 $\quad(\mathrm{P}<0.01), \quad \mathrm{T} 7$ $(\mathrm{P}<0.01), \mathrm{T} 8(\mathrm{P}<0.05)$ and $\mathrm{T} 12(\mathrm{P}<0.05)$. In the GO group, it was observed at $\mathrm{T} 1(\mathrm{P}<0.001), \mathrm{T} 2$ $(\mathrm{P}<0.001), \quad \mathrm{T} 3 \quad(\mathrm{P}<0.001), \mathrm{T} 4 \quad(\mathrm{P}<0.001), \mathrm{T} 5$ $(\mathrm{P}<0.01)$ and $\mathrm{T} 6(\mathrm{P}<0.05)$.

There was no statistically significant difference between the groups regarding the presence of ocular discharge and blepharospasm. In the GO group, a whitish and gelatinous eye discharge was present from $\mathrm{T} 7$ onward.

The extent of conjunctival hyperemia at $\mathrm{T} 1$ $(\mathrm{P}<0.05)$ in the GO group and T3 $(\mathrm{P}<0.05)$ in the GB group was significantly different from that at other times in each group.

At 7 days after surgery, most of the animals in the GO group exhibited a mild acute inflammatory response, with mononuclear cell infiltration, foreign body reaction, moderate infiltration of eosinophils and minor formation of granulation tissue (fibroplasia, angiogenesis and the production of fibrous connective tissue) (Fig. 2A). In this phase, marked necrosis and sloughing of the nasolacrimal duct epithelium (Fig. 3A) was observed. In some of the samples, biomaterial was observed within the duct. All of the animals in the GB group displayed a marked acute inflammatory response, and most of them exhibited a mild foreign body reaction and marked infiltration of eosinophils. Compared to the GB group, the repair phenomena for the GO group were accentuated (fibroplasia and angiogenesis) in most of the animals, and intense epithelial cell desquamation, red cells and marked eosinophilic material (fibrin) were inside the nasolacrimal duct (Fig. 3B).

At 14 days postoperative, the GO samples displayed a clear reduction of the eosinophilic inflammatory infiltrate and the absence of giant cells or evidence of acute inflammatory phenomena (Fig. 2C). The nasolacrimal duct epithelium showed extensive areas of reepithelialization and mild desquamation (Fig.
3C). At this time, in the GB group, a foreign body reaction, the presence of mature fibrous tissue and re-epithelialization were predominant (Fig. 2D). Desquamated epithelial cells, red cells and a moderate amount of eosinophilic material (fibrin) persisted within the nasolacrimal duct (Fig. 3D)

Histological examination revealed that the exudative inflammatory phenomena had decreased by day 14 , at which time the reparative and epithelial regenerative phenomena prevailed in both groups (Tab. 1).

\section{DISCUSSION}

Rabbits have been used as experimental models for numerous studies in ophthalmology (Williams, 2007). Paulsen et al. (2002) studied the lacrimal system in various species, including rabbits. The lacrimal system of this species is composed of an extensive pseudostratified columnar epithelium with two layers, one layer of basal cells and a superficial layer of columnar cells capped by microvilli, as well as a cavernous region surrounded by blood vessels, which is very similar to human lacrimal system. The characteristics of this system allow the absorption of products and enable this species to be a model for testing the toxicity and absorption of ophthalmologic drugs. In addition to the above-mentioned factors, the choice of this species for the present study was based on the ease of its handling.

Using and handling of the adhesives, as previously described, proved to be simple and feasible and did not provoke complications, such as those reported by Rosa (2011) when ethylcyanoacrylate in the liquid form was placed in the nasolacrimal ducts of dogs. The author used a needle sliced in half as a cannula and reported that the adhesive adhered internally to it before it was applied. Still, it was noted difficult adhesion of the glue to the nasolacrimal duct and its exit throughout the cannula, after its removal. 

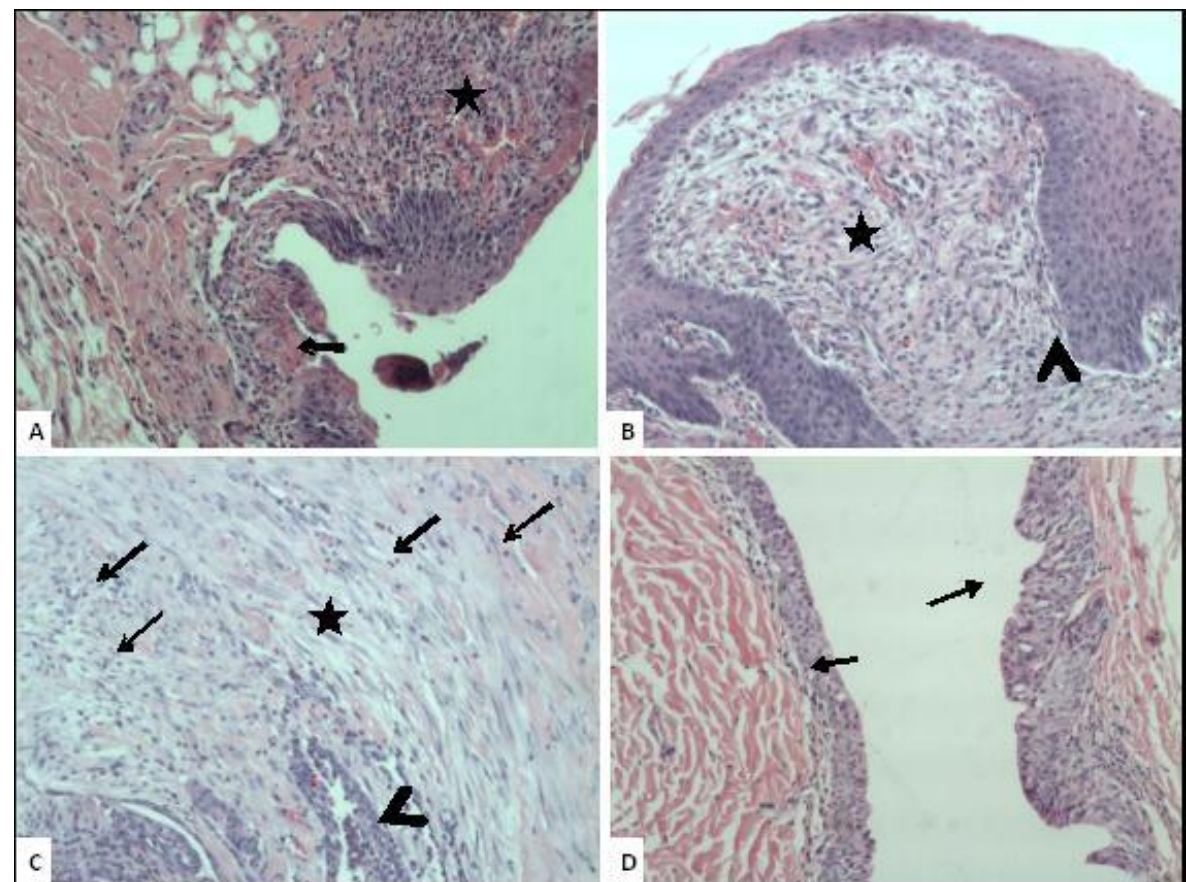

Figure 2. Photomicrographs of rabbit nasolacrimal ducts. A, 7 days post-occlusion with n-butyl-cyanoacrylate, showing moderate eosinophilic and mononuclear infiltrates (star) in the periodical region with foci of epithelial necrosis (arrow) and reepithelialization (arrowhead) in the duct (HE, 40x); B, 7 days post-occlusion with 2-octyl-cyanoacrylate, showing fibroplasia with new fibrous tissue, neovascularization (star) and re-epithelialization (arrowhead) (HE, 200x); C, 14 days post-occlusion with nbutyl-cyanoacrylate, showing fibroplasia with mature fibrous tissue (star), discrete eosinophilic infiltrate (arrow) and reepithelialization (arrowhead) (HE, 40x); D, 14 days post-occlusion with 2-octyl-cyanoacrylate, showing tear duct re-epithelialization (arrow) (HE, 200x).

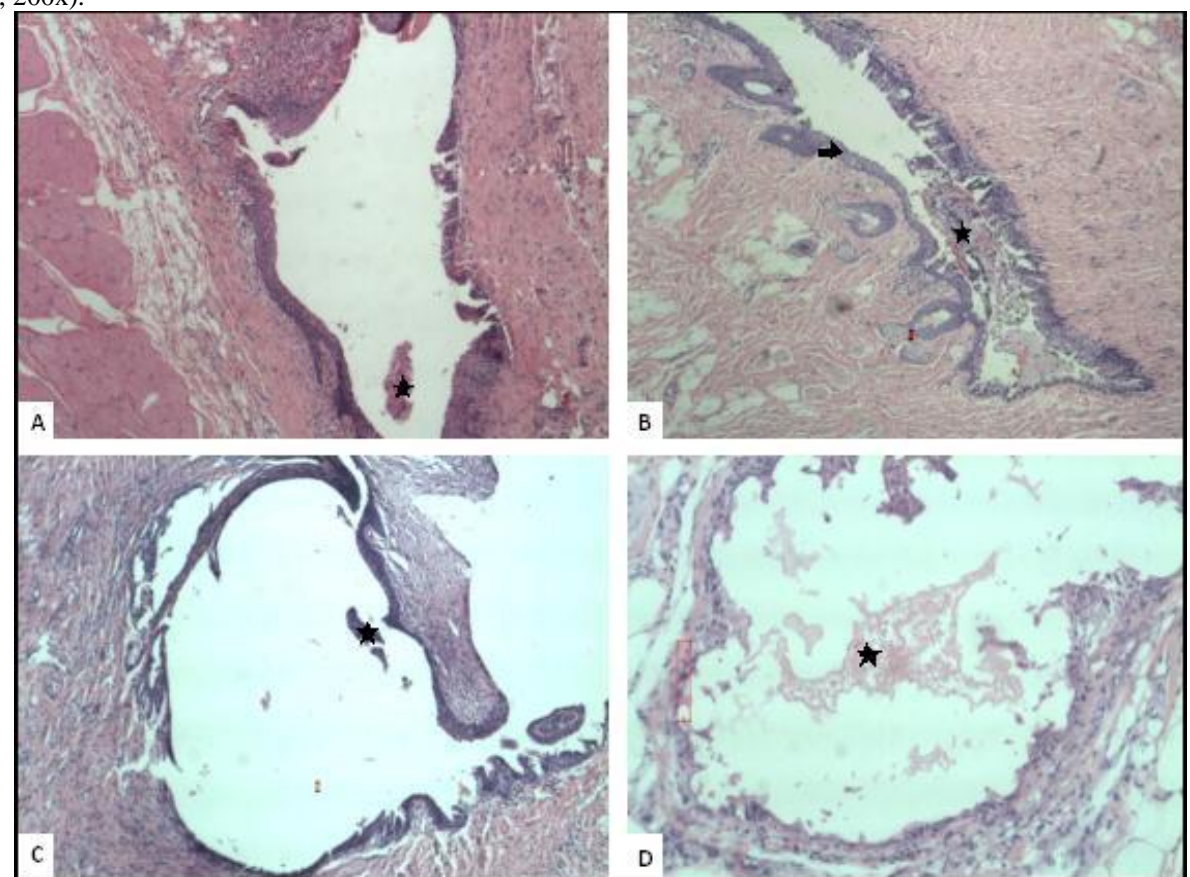

Figure 3. Photomicrographs of rabbit nasolacrimal ducts. A, 7 days post-occlusion with n-butyl-cyanoacrylate, showing moderate cell shedding in the duct inward (star) (HE, 200x); B, 7 days post-occlusion with 2-octyl-cyanoacrylate, showing a high content of erythrocytes, fibrin and desquamated cells in the duct light (star) and ductal re-epithelialization (arrow), (HE, 40x); C, 14 days postocclusion with n-butyl-cyanoacrylate, showing discrete quantity of exfoliated cells in the duct (star), (HE, 40x); D, 14 days postocclusion with 2-octyl-cyanoacrylate, showing moderate content of erythrocytes, fibrin and desquamated cells in the duct inward (star) (HE, 200x). 
Table 1. Scores (0 - absent, 1 - mild, 2 - moderate and 3 - severe) and percentage $(\%)$ values for the following variables: eosinophilic inflammatory infiltrate (EII), foreign body reaction (FBR), new granulation tissue (NGT), mature granulation tissue (MGT) and acute inflammatory reaction (AIR) observed upon histological evaluation of the rabbit nasolacrimal ducts harvested at seven and 14 days after occlusion with n-butyl-cyanoacrylate (GB) or 2-octyl-cyanoacrylate (GO).

\begin{tabular}{|c|c|c|c|c|c|c|c|c|c|}
\hline \multirow{3}{*}{$\begin{array}{c}\text { Score } \\
\text { Variables }\end{array}$} & \multirow[t]{2}{*}{ Time } & \multicolumn{4}{|c|}{7 days } & \multicolumn{4}{|c|}{14 days } \\
\hline & & 0 & 1 & 2 & 3 & 0 & 1 & 2 & 3 \\
\hline & Group & & & & & & & & \\
\hline \multirow{4}{*}{ EII } & \multirow{2}{*}{ GB } & 0 & 0 & 2 & 3 & 1 & 4 & 0 & 0 \\
\hline & & - & - & (40) & $(60)$ & $(20)$ & $(80)$ & - & - \\
\hline & \multirow{2}{*}{ GO } & 2 & 0 & 1 & 2 & 0 & 4 & 0 & 1 \\
\hline & & (40) & - & (20) & (40) & - & (80) & - & (20) \\
\hline \multirow{4}{*}{ FBR } & \multirow{2}{*}{ GB } & 0 & 5 & 0 & 0 & 1 & 0 & 3 & 1 \\
\hline & & - & (100) & - & - & (20) & - & (60) & (20) \\
\hline & \multirow{2}{*}{$\mathrm{GO}$} & 0 & 2 & 2 & 1 & 4 & 1 & 0 & 0 \\
\hline & & - & (40) & (40) & (20) & $(80)$ & (20) & - & - \\
\hline \multirow{4}{*}{ NGT } & \multirow{2}{*}{ GB } & 0 & 0 & 2 & 3 & 4 & 1 & 0 & 0 \\
\hline & & - & - & (40) & (60) & (80) & (20) & - & - \\
\hline & \multirow{2}{*}{ GO } & 2 & 1 & 0 & 2 & 4 & 1 & 0 & 0 \\
\hline & & (40) & (20) & - & (40) & (80) & (20) & - & - \\
\hline \multirow{3}{*}{ MGT } & \multirow{2}{*}{ GB } & 5 & 0 & 0 & 0 & 0 & 1 & 2 & 2 \\
\hline & & $(100)$ & - & - & - & - & (20) & (40) & (40) \\
\hline & GO & $\begin{array}{c}2 \\
(40)\end{array}$ & $\begin{array}{c}1 \\
(20)\end{array}$ & 0 & $\begin{array}{c}2 \\
(40)\end{array}$ & $\begin{array}{c}3 \\
(60)\end{array}$ & 0 & $\begin{array}{c}1 \\
(20)\end{array}$ & $\begin{array}{c}2 \\
(40)\end{array}$ \\
\hline \multirow{4}{*}{ AIR } & \multirow{2}{*}{ GB } & 0 & 0 & 0 & 5 & 4 & 1 & 0 & 0 \\
\hline & & - & - & - & (100) & $(80)$ & (20) & - & - \\
\hline & \multirow{2}{*}{$\mathrm{GO}$} & 1 & 3 & 1 & 0 & 5 & 0 & 0 & 0 \\
\hline & & (20) & (60) & (20) & - & (100) & - & - & - \\
\hline
\end{tabular}

To minimize such variations in this study, the measurements were conducted during the same time period and by the same professional, using test materials from the same batch. Moreover, the values obtained at T0 are consistent with those observed by Bolzan et al. (2008), who assessed the tear production of 25 New Zealand albino rabbits and obtained a mean vale of $7.78 \pm 2.21 \mathrm{~mm} / \mathrm{min}$ in an environment and under conditions similar to those of this study.

The higher values of the Schirmer tear test and the presence of epiphora in the treated eyes demonstrated the efficacy of occlusion in both groups during the 14-day trial. The duration of the occlusion may vary according to the amount of material and technique applied. Patel and Grierson (1994) placed collagen implants in human lacrimal puncta and reported the dissolution of this material in five of the six eyes over a period of seven days. Moreover, Diamond et al. (1995) occluded the nasolacrimal ducts of eight patients using an n-butyl-cyanoacrylate adhesive and observed efficacy for more than nineteen months. Previously, Patten (1976) instilled this adhesive into the lacrimal point and found that the occlusion persisted for two and a half weeks (Diamond et al., 1995).

In this study, we used the Schirmer tear I test, which does not suppress the contribution of reflex tearing. This Schirmer test indicated that the slight increase in the values observed in the control eyes in this study, on the days after occlusion, as well as the marked increase of the value in the GB group from T6 could result from the effect of bilateral stimulation due to the presence of the adhesive in the treated eyes and the degree of inflammation that it caused. Corroborating this conjecture, Wagner and Fehr (2007) reported that the occurrence of epiphora in lagomorphs is related to increased lacrimation resulting from eye irritation or decreased drainage, the latter of which is related to rhinitis and dacryocystitis (Williams, 2007). Both issues could have been caused by the presence of an adhesive. 
The flexibility of the adhesives in the ducts is related to their chain length, such that the shorter the length, the lower the adhesive's flexibility, tensile strength and degradation time and the greater is its adhesion (Chow et al., 2010). Thus, it may be inferred that due to the greater flexibility of octyl-cyanoacrylate compared to that of n-butyl-cyanoacrylate, its presence would be less cumbersome and would stimulate less reflex tearing.

Cyanoacrylates are indicated for topical use, and when they are not topical, their biocompatibility may change, which may lead to chronic granulomatous inflammation, tissue necrosis and a predisposition to infections and pain (Gasset et al., 1970; Quinn et al., 1997; Reece et al., 2001). Cyanoacrylates, such as 2-octyl-cyanoacrylate, contain a long carbon chain that hampers their degradation and therefore increases the accumulation of by-products, which have significant tissue toxicity and induce a high degree of inflammation (Woodward et al., 1965; Quinn et al., 1997; Vote and Elder, 2000; Marcovich et al., 2001). This process was corroborated by the histological changes observed in the GO group at day seven, such as the mild and moderate acute inflammatory and foreign body responses, followed by the resolution of the inflammatory response and the absence of a foreign body response at day 14 . The striking necrosis and epithelial sloughing present in the nasolacrimal duct at day seven, which evolved to re-epithelialization at day 14 , demonstrated that reparative phenomena occurred rapidly in this group. However, conjunctival hyperemia was pronounced at $\mathrm{T} 1$, which could be related to the foreign body reaction caused by this adhesive.

The opposite response was observed in the GB group, in which the adhesive is composed of a carbon chain shorter than that of 2-octylcyanoacrylate, which therefore raised a greater acute inflammatory response on the seventh trial day. The conjunctival hyperemia that was significant at T3 may have indicated the onset of the foreign body reaction later observed in this group.

\section{CONCLUSIONS}

This study demonstrated that both adhesives were effective in obstructing the nasolacrimal ducts and points of rabbits and that their application and handling are easy and free of complications. However, both adhesives promoted inflammatory and foreign body reactions that evolved to repair and regeneration at day 14 of evaluation.

\section{ACKNOWLEDGEMENTS}

We thank CAPES and CNPq for the scholarships provided.

\section{REFERENCES}

ABRAMS, K.L.; BROOKS, D.E.; FUNK, R.S.; THERAN, P. Evaluation of the Schirmer tear test in clinically normal rabbits. Am. J. Vet. Res., v.51, p.1912-1913, 1990.

BERGER, S.L.; KING, V.L. The fluctuation of tear production in the dog. J. Am. Anim. Hosp. Assoc., v.34, p.79-83, 1998.

BERGER, S.L.; SCAGLIOTTI, R.H.; LUND, E.M. A quantitative study of the effects of tribissen on canine tear production. J. Am. Anim. Hosp. Assoc., v.31, p.236-241, 1995.

BIRICIK, H.S. Evaluation of the Schirmer and phenol red thread tests for measuring tear secretion in rabbits. Vet. Rec., v.156, p.485-487, 2005.

BOLZAN, A.A.; HONSHO, C.S.; ANDRADE, J.N.B.M. et al. Mensuração da produção lacrimal em coelhos albinos da raça Nova Zelândia com o teste de Schirmer. In: CONGRESSO BRASILEIRO DA ANCLIVEPA, 29., 2008, Maceio. Anais..., Maceió: 2008. Cd-rom.

CHOW, A.; MARSHALL, H.; ZACHARAKIS, E. $e t$ $a l$. Use of Tissue Glue for Surgical Incision Closure: A Systematic Review and Meta-Analysis of Randomized Controlled Trials. J. Am. Coll. Surg., v.211, p.114-125, 2010.

DIAMOND, J.P.; MORGAN, J.E.; VIRJEE, J.; EASTY, D.L. Cannalicular occlusion with cyanoacrylate adhesive: a new treatment for the dry eye. Eye, v.9, p.126-129, 1995.

GASSET, A.R.; HOOD, C.I.; ELLISON, E.D.; KAUFMAN, H.E. Ocular tolerance to cyanoacrylate monomer tissue adhesive analogues. Invest. Ophthalmol. Vis. Sci., v.9, p.3-11, 1970. 
GIULIANO, E.A.; MOORE, C.P. Diseases and surgery of the lacrimal secretory system. In: GELATT, K.N. Veterinary ophthalmology. 4.ed. Oxford: Blackwell Publishing, 2007. p.633-661.

GUM, G.G; GELATT, K.N.; ESSON, D.W. Physiology of the eye. In: GELATT, K.N. Veterinary ophthalmology. 4.ed. Oxford: Blackwell Publishing. 2007, p.149-182.

HARTLEY, C.; WILLIAMS, D.L; ADAMS, V.J. Effect of age, gender, weight, and time of day on tear production in normal dogs. Vet. Ophthalmol., v.9, p.53-57, 2006.

HERRERA, H.D.; WEICHSLER, N.; GÓMEZ, J.R.; DE JALÓN, J.A. Severe, unilateral, unresponsive keratoconjunctivitis sicca in 16 juvenile Yorkshire Terriers. Vet. Ophthalmol., v.10, p.285-288, 2007.

KOÇ, Y.; ALKAN, F.; TEPELİ, C. Schirmer tear test in different rabbits breeds. Hayvancilik Arastirma Dergisi, v.15, p.1-5, 2005. Disponível em: http://dosya.bdutae.gov.tr/makale1-2005-2.pdf. Acessado em: 8 out. 2012.

MARCOVICH, R.; WILLIAMS, A.L.; RUBIN, M.A.; WOLF. J.S. Comparison of 2-octyl cyanoacrylate adhesive, fibrin glue, and suturing for wound closure in the porcine urinary tract. Urinary, v.4, p.806-810, 2001.

MURUBE, J.; MURUBE, E. Treatment of dry eye by blocking the lacrimal canaliculi. Surv. Ophthalmol., v.40, p.463-480, 1996.

OHBA, E.; DOGRU, M.; HOSAKA, E. et al. Surgical punctal occlusion with a high heat-energy releasing cautery device for severe dry eye with recurrent punctal plug extrusion. Am. J. Ophthalmol., v.151, p.483-487, 2011.

PATEL, S.; GRIERSON, D. Effect of collagen punctal occlusion on tear stability and volume. Adv. Exp. Med. Biol., v.350, p.605-608, 1994.

PATTEN, J.T. Punctal occlusion with n-butyl cyanoacrylate tissue adhesive. Ophthalmic. Surg., v.7, p.24-26, 1976.

PAULSEN, F.P.; FÖGE, M.; THALE, A.B. et al. Animal model for the absorption of lipophilic substances from tear fluid by the epithelium of the nasolacrimal ducts. Invest. Ophthalmol. Vis. Sci., v.43, p.3137-3143, 2002.
QUINN, J.; WELLS, G.; SUTCLIFFE, T. et al. A Randomized Trial Comparing Octylcyanoacrylate Tissue Adhesive and Sutures in the Management of Lacerations. JAMA, v.277, p.1527-1530, 1997.

REECE, T.B.; MAXEY, T.S.; KRON, I.L. A prospectus on tissue adhesives. Am. J. Surg., v.182, p.40-44, 2001.

ROSA, A.S. Utilização do etil-cianoacrilato no tratamento da ceratoconjuntivite seca através da obstrução do ducto nasolacrimal de cães. 2011. 37f. Dissertação (Mestrado em Medicina Veterinária), Universidade Federal Rural do Rio de Janeiro, Seropédica.

SERIN, D.; KARSLOĞLU, S.; KYAN, A.; ALAGÖZ, G. A simple approach to the repeatability of the Schirmer test without anesthesia. Cornea, v.26, p.903906, 2007.

SLATTER, D. Fundamentos de oftalmologia veterinária. 3. ed. São Paulo: Roca, 2005. 686p.

VOTE, B.J.T.; ELDER, M.J. Cyanoacrylate glue for corneal perforations: a description of a surgical technique and a review of the literature. Clin. Experiment. Ophthalmol., v.28, p.437-442, 2000.

WAGNER, F.; FEHR, M. Common Ophthalmic Problems in Pet Rabbits. J. Exot. Pet Med., v.16, p.158-167, 2007.

WILLIAMS, D.L. Immunopathogenesis of keratoconjunctivitis sicca in the dog. Vet. Clin. N. Am.: Small Anim. Pract., v.38, p.251-268, 2008.

WILLIAMS, D. Laboratory animal ophthalmology. In: GELATT, K.N. Veterinary Ophthalmology. 4.ed. Iowa: Blackwell Publishing, 2007. p.1336-1369.

WOERDT, A.; ADAMCAK, A. Comparison of absorptive capacities of original and modified Schirmer tear test strips in dogs. J. Am. Vet. Med. Assoc., v.216, p.1576-1577, 2000.

WOODWARD, C.S.C.; HERRMANN, J.B.; CAMERON, J.L. et al. Histotoxicity of cyanoacrylate tissue adhesive in the rat. Ann. Surg., v.162, p.113122, 1965. 